\title{
Targets for the reduction of antibiotic use in humans in the Transatlantic Taskforce on Antimicrobial Resistance (TATFAR) partner countries
}

Fabio D’Atri ${ }^{1,2}$, Jacqueline Arthur ${ }^{3}$, Hege Salvesen Blix ${ }^{4}$, Lauri A Hicks ${ }^{5}$, Diamantis Plachouras ${ }^{1}$, Dominique L Monnet ${ }^{1}$, the

European Survey on Transatlantic Task Force on Antimicrobial Resistance (TATFAR) action 1.2 group ${ }^{6}$

1. European Centre for Disease Prevention and Control (ECDC), Stockholm, Sweden

2. European Commission, Directorate General for Health and Food Safety, Brussels, Belgium

3. Centre for Communicable Diseases and Infection Control, Public Health Agency of Canada, Ottawa, Canada

4. Norwegian Institute of Public Health, Oslo, Norway

5. Office of Antibiotic Stewardship, Division of Healthcare Quality Promotion, Centers for Disease Control and Prevention, Atlanta, United States

6. The members of the European Survey on TATFAR action 1.2 group are listed at the end of the article

Correspondence: Diamantis Plachouras (diamantis.plachouras@ecdc.europa.eu)

Citation style for this article:

D’Atri Fabio, Arthur Jacqueline, Blix Hege Salvesen, Hicks Lauri A, Plachouras Diamantis, Monnet Dominique L, the European Survey on Transatlantic Task Force on Antimicrobial Resistance (TATFAR) action 1.2 group. Targets for the reduction of antibiotic use in humans in the Transatlantic Taskforce on Antimicrobial Resistance (TATFAR) partner countries. Euro Surveill. 2019;24(28): pii=1800339. https://doi.org/10.2807/1560-7917.ES.2019.24.28.1800339

Unnecessary and inappropriate use of antibiotics in human healthcare is a major driver for the development and spread of antimicrobial resistance; many countries are implementing measures to limit the overuse and misuse of antibiotics e.g. through the establishment of antimicrobial use reduction targets. We performed a review of antimicrobial use reduction goals in human medicine in Transatlantic Taskforce on Antimicrobial Resistance partner countries. On 31 March 2017, the European Centre for Disease Prevention and Control sent a questionnaire to National Focal Points for Antimicrobial Consumption and the National Focal Points for Antimicrobial Resistance in 28 European Union countries, Iceland and Norway. The same questionnaire was sent to the TATFAR implementers in Canada and the United States. Thirty of 32 countries replied. Only nine countries indicated that they have established targets to reduce antimicrobial use in humans. Twenty-one countries replied that no target had been established. However, 17 of these 21 countries indicated that work to establish such targets is currently underway, often in the context of developing a national action plan against antimicrobial resistance. The reported targets varied greatly between countries and can be a useful resource for countries willing to engage in the reduction of antibiotic use in humans.

\section{Background}

Inappropriate and unnecessary use of antibiotics in human healthcare-i.e. ambulatory, hospital and long-term care-is a major driver for the development and spread of antimicrobial resistance. According to data collected by the Organisation for Economic Co-operation and Development (OECD), inappropriate use of antibiotics may account for up to $50 \%$ of all antimicrobials used in human healthcare and may be as high as $90 \%$ in long-term care facilities and ambulatory care [1]. The establishment of antimicrobial use reduction targets has been proposed as one of several measures to curb the unnecessary use of antibiotics $[2]$.

In the 2009 European Union (EU)-United States (US) Summit Declaration, the Transatlantic Taskforce on Antimicrobial Resistance (TATFAR) was established to address urgent antimicrobial-resistance issues [3]. In 2015, the TATFAR collaboration was extended to 2020; a revised work plan of 20 actions was created and two additional countries joined: Canada and Norway [4]. The TATFAR action 1.2 comprises a review of implemented or planned antimicrobial reduction goals, in human medicine in TATFAR partner countries, as provision of a comprehensive list of these targets would facilitate the work of other countries that would like to establish such targets. This action was implemented jointly by the European Centre for Disease Prevention and Control (ECDC), the US Centers for Disease Control and Prevention (CDC), the Public Health Agency of Canada (PHAC) and the Norwegian Institute for Public Health (NIPH).

\section{Survey}

A questionnaire was developed by ECDC with input from TATFAR partners (Supplementary material). On 31 March 2017, ECDC sent the questionnaire to the 28 EU countries, Iceland and Norway via an email to the National Focal Points for Antimicrobial Consumption and the National Focal Points for Antimicrobial 
Resistance with a deadline for reply of 31 May 2017. Reminders were sent via email during the month of June 2017. The National Focal Points are nominated by the Coordinating Competent Body of each EU/ European Economic Area country and are responsible for overseeing interactions between their country and ECDC regarding activities related to the disease group for which they are nominated. They can be employed in public authorities (ministries, public health institutes, medicines agencies or other respective structures), healthcare or academia and can be members of the European Antimicrobial Resistance Surveillance Network (EARS-Net) or the European Surveillance of Antimicrobial Consumption Network (ESAC-Net). The same questionnaire was also used to collect data from TATFAR partners in Canada and the US. In total, the questionnaire was sent to 32 countries.

The questionnaire comprised 12 questions and addressed whether the country had established or was planning to establish targets to reduce antibiotic use, the rationale, baseline and timeline for achieving the targets, how progress was monitored and the status of the targets.

\section{Survey findings}

Replies were received from 30 of 32 countries. No replies were received from the National Focal Points for Cyprus and Portugal. Nine countries indicated that they have established targets to reduce antibiotic use in humans.

\section{Belgium}

In Belgium, addressing antimicrobial resistance has been high on the political agenda since the 1990s, when the country had one of the highest rates of antibiotic consumption in the EU. For this reason, a Belgian Antibiotic Policy Coordination Commission (BAPCOC) was founded in 1999. In 2013, the third National Strategic Plan to fight against antimicrobial resistance 2014-19 was adopted [5].

In ambulatory care (baseline 2014), the following targets for antimicrobial use in humans, i.e. antibacterials for systemic use, were set [6]: (i) a decrease in total antibiotic prescription rate from > 800 prescriptions per 1,000 inhabitants per year to $\leq 600$ prescriptions per 1,000 inhabitants per year by 2020 , and $\leq 400$ prescriptions per 1,000 inhabitants per year by 2025 , (ii) a decrease in quinolone consumption from ca $10 \%$ of total antibiotic consumption in 2014 to $5 \%$ by 2018 (to curb the overconsumption of fluoroquinolones) and, (iii) an increase in the prescription ratio of amoxicillin vs amoxicillin-clavulanic acid from ca 50/50 in 2014 to $80 / 20$ by 2018 (to curb the overconsumption of broadspectrum combinations of penicillins).

For the hospital sector, Belgium did not set quantity metrics but rather indicators for the quality of antibiotic prescriptions, such as the proportion of therapeutic antibiotics that were chosen following local guidelines; this should be at least 90\% by 2019 . Comparisons between point prevalence surveys performed on a regular basis (2015, 2017 and 2019) [7] are used to determine whether local interventions in participating hospitals are successful. Mandatory surveillance of total antibiotic consumption is implemented since 2007 in all Belgian general hospitals, providing local feedback as well as national consumption levels, but no national quantitative target is associated with this data collection.

\section{France}

At the end of the 1990s, France had a very high consumption of antibiotics-more than 36 defined daily doses (DDD) per 1,000 inhabitants per day in 2000. Reduction of antibiotic consumption has been a key focus of the national action plans introduced since 2001. Despite the lack of specific targets, awareness campaigns directed at both the general public and health professionals resulted in a more than $15 \%$ reduction of antibiotic consumption during 2002-05. A more modest decrease was observed in the following 5 years.

In 2011, a target to decrease antibiotic consumption by $25 \%$ by 2016 (applying to all antibiotics for systemic use and measured as DDD per 1,000 inhabitants per day) was introduced as part of the national action plan for $2011-16$ [8].

In addition, targets linked to a pay-for-performance system were implemented [9] and financial rewards were introduced in 2011. For general practitioners (GPs), the annual antibiotic prescription rate in patients aged 16-65 years without a chronic disease was to decrease to 14 treatments per 100 patients, with an intermediate objective of 25 treatments per 100 patients. Moreover, the proportion of patients treated with 'critical antibiotics' (amoxicillin-clavulanic acid, third- and fourthgeneration cephalosporins, fluoroquinolones) was not to exceed $27 \%$ of the annual antibiotic prescription rate. For paediatricians, < $3 \%$ of patients $<4$ years old or $<2 \%$ of those $\geq 4$ years old were to be treated with third- or fourth-generation cephalosporins. The system was renewed and reinforced in 2016 [10].

The French Medicines Agency (ANSM) compiles data on overall antibiotic consumption annually for both the ambulatory and the hospital sector based on sales figures provided by pharmaceutical companies. In addition, a national network of hospitals (ATB-Raisin network) collects antibiotic consumption data from hospital pharmacies on a voluntary basis. Based on these data, the $25 \%$ antibiotic consumption reduction target was not achieved by 2016 . Instead, consumption had slightly increased between 2011-15. However, the pay-for-performance targets appear to have nearly achieved their objectives in GPs and paediatricians for the period 2011-16. The number of antibiotic prescriptions per 100 patients aged 16-65 years decreased 
from 45.7 in 2011 to 39.5 in 2016 (close to the target of 37 ) and further decreased to 36.1 in 2017.

\section{Malta}

Malta plans to reduce prescribing of carbapenems without previous consultation with a microbiologist or infectious disease specialist by $75 \%$ by the end of 2020 , as compared with the level in 2016 . There are also goals to reduce the overall consumption of carbapenems (measured in DDD per 1,000 bed-days) in hospital care by at least $10 \%$ during the same time period (M.A. Borg, personal communication, 10 May 2019).

\section{The Netherlands}

The Netherlands reports one of the lowest antibiotic consumption rates in the EU. Nevertheless, reduction of inappropriate use of antibiotics is one of the objectives of the 2015-19 national action plan against antimicrobial resistance $[11,12]$ : 'the reduction of at least $50 \%$ in the use of incorrectly prescribed antibiotics across the entire healthcare chain, relative to a baseline determined with stakeholders. Differences between healthcare domains and practice variation within one domain will be taken into account...It is important to consider agreements about prescription behaviour within the context of quality of care; both over-treatment with antibiotics and under-treatment will be taken into consideration'.

While some baseline data on inappropriate prescriptions are available for the ambulatory care sector [13-16], this is not yet the case for the hospital and long-term care sectors. An expert working group has been established and has set up a national programme to reduce the inappropriate use of antibiotics, including pilot projects to assess antibiotic use in ambulatory, hospital and long-term care sectors.

\section{Norway}

Despite the relatively low use of antibiotics in Norway, national studies targeting GPs have identified the potential to further reduce the volume of prescribed antibiotics, as well as to further shift antibiotic prescribing towards even more narrow-spectrum antibiotics. The 2015-20 multisectoral strategy against antimicrobial resistance includes specific targets for the reduction of antibiotic use in humans [17].

For ambulatory care, it aims: (i) to reduce antibiotic consumption by $30 \%$ (measured as DDD per 1,000 inhabitants per day) by 2020 compared with 2012 consumption, (ii) to reach, by 2020 , an average of 250 prescriptions of antibiotics per 1,000 inhabitants per year, and (iii) to reduce the number of prescriptions of antibiotics to treat respiratory infections by $20 \%$ (measured in DDD per 1,000 inhabitants per day) by 2020 compared with 2012.

In addition to the above targets, national treatment guidelines aim: (i) to increase the relative proportion of phenoxymethylpenicillin prescribed for respiratory tract infections in children aged $0-6$ years to $80 \%$ of all antibiotics prescribed for respiratory tract infections in the same patient group, and (ii) to reduce the prescription rate of fluoroquinolones (and, in particular, ciprofloxacin) for treating uncomplicated urinary tract infections in women aged 20-79 years to less than $8 \%$ of all antibiotics prescribed for urinary tract infections in the same patient group. The National Antibiotic Committee has also agreed to a 30\% reduction (measured as prescriptions per 1,000 inhabitants per year) of antibiotic prescriptions for respiratory tract infections in children aged $0-6$ years.

In the hospital care sector, Norway aims to achieve a $30 \%$ reduction (measured as DDD per 100 beds per day) of the use of broad-spectrum antibiotics by 2020 compared with the 2012 baseline.

Data concerning antibiotic prescriptions and antibiotic consumption are regularly collected from wholesalers, hospitals and pharmacies and are reported in national registries. These data are continuously collected and regularly discussed with relevant stakeholders. The data collected until 2016 show an overall 11\% decrease in antibiotic consumption (measured as DDD per 1,000 inhabitants per day) compared with 2012. To improve and verify the compliance of antibiotic prescriptions with national guidelines, the Norwegian parliament has decided to introduce requirements for diagnostic codes on prescriptions of antibiotics, in a way that safeguards patient privacy.

\section{Slovenia}

The national antimicrobial resistance strategy includes actions to decrease antibiotic consumption by $20 \%$ in ambulatory care and by $10 \%$ in hospital care by 2024 compared with 2017 data (M. Čižman, personal communication, 15 May 2019). For example, in ambulatory care the objective is to reduce the consumption of antibiotics for systemic use (Anatomic Therapeutic Chemical, group J01) from 13.9 DDD per 1,000 inhabitants per day in 2016 to 11 DDD per 1,000 inhabitants per day in 2022. In ambulatory care, a particular emphasis is being placed on decreasing the number of antibiotic prescriptions for children, in particular amoxicillinclavulanic acid, azithromycin and fluoroquinolones. Furthermore, actions will be introduced to reduce the rates of antibiotic prescriptions in patients with acute otitis media, sinusitis, throat infections, bronchitis and unspecified upper respiratory tract infections.

In hospital care, the aim is to decrease the use of third-generation cephalosporins, fluoroquinolones and carbapenems. Monitoring antibiotic consumption in long-term care facilities is also planned.

National antibiotic consumption data show that, in 2016, the consumption of antibiotics in ambulatory care in many regions of Slovenia has been $4.9 \%$ (measured as DDD per 1,000 inhabitants per day), which is lower than in 2015. 


\section{Sweden}

The revised Swedish antimicrobial resistance strategy [18], like previous versions of this strategy, supports the national targets based on sales data elaborated by the Swedish Strategic Programme against Antibiotic Resistance (Strama) [19]. Experts within the Strama network have developed indicators on the basis of surveys in the ambulatory care [20] and hospital care [21] sectors.

According to the Swedish antimicrobial resistance strategy, the total number of antibiotic prescriptions in Swedish ambulatory care (sales of all antibiotics within ATC group J01, except methenamine, dispensed by all Swedish pharmacies) should not exceed 250 per 1,000 inhabitants per year (long-term goal). In addition, a minimum of $80 \%$ of all antibiotics used to treat respiratory tract infections in children aged 0-6 years should be phenoxymethylpenicillin (Numerator: sales of penicillin $\mathrm{V}$ (J01CE02) dispensed on prescription by all Swedish pharmacies, all package sizes; denominator: sales of prescribed amoxicillin (Jo1CAo4), phenoxymethylpenicillin (J01CE02), amoxicillin-clavulanic acid (Jo1CRo2), cephalosporins (Jo1DB-DE) and macrolides (Jo1FA) dispensed by Swedish pharmacies, all package sizes). Further, a maximum of $10 \%$ of all antibiotics used to treat urinary tract infections in women aged 18-79 years should be fluoroquinolones (Numerator: sales of ciprofloxacin (Jo1MAo2) and norfloxacin (Jo1MA06), all packages sizes; denominator: sales of prescribed pivmecillinam (Jo1CA08), trimethoprim (Jo1EA01), ciprofloxacin (Jo1MA02), norfloxacin (Jo1MA06) and nitrofurantoin (Jo1XE01) dispensed by Swedish pharmacies).

In addition to these targets, diagnosis-related targets are suggested by the Strama Programme Council operational plan for 2019 [22].

For ambulatory care, more than $80 \%$ of women and more than $50 \%$ of men with afebrile urinary tract infection should receive first-line treatment, more than $90 \%$ of patients treated against pharyngotonsillitis should receive penicillin $V$ and less than $10 \%$ of patients with acute bronchitis should receive antibiotic treatment.

For hospital care, more than $60 \%$ of patients with community-acquired pneumonia and not requiring intensive care should be initially treated with penicillin and more than $90 \%$ of patients with afebrile urinary tract infection should receive first-line treatment.

Antibiotic sales data are collected and sent by the Public Health Agency of Sweden (PHA) to the Strama Programme Council and to each local Strama group, and are compiled in the annual report on antibiotic use and resistance in humans and animals in Sweden (Swedres-Svarm). The targets for ambulatory care are also monitored via the Primary Care Quality national register, while Sweden plans to monitor the targets for hospital care on a local basis via the Infection Tool (Inera).

There has been a slow but steady decrease of antibiotic prescriptions in ambulatory care in Sweden since the mid-1990s. Although there was no change in total antibiotic use in hospital care during 2000-16, a shift from broad-spectrum antibiotics to narrow-spectrum antibiotics has been reported.

\section{United Kingdom}

The need to optimise prescribing practices is one of the key objectives of the UK Five Year Antimicrobial Resistance Strategy 2013-18 [23]. The UK government aims to reduce inappropriate antibiotic prescriptions by $50 \%$ by 2020 . In order to implement the national strategy, England and each of the devolved administrations has developed its own objectives.

England has introduced financial incentives linked to specific objectives and targets both for ambulatory care [24] and for hospitals [25]. For ambulatory care, one of the indicators is the reduction of inappropriate antibiotic prescribing for urinary tract infections. For the period 2017-18, the target (based on June 2015May 2016 baseline data) is a minimum 10\% reduction in the trimethoprim/nitrofurantoin prescribing ratio and at least a $10 \%$ reduction in trimethoprim items prescribed to patients aged $\geq 70$ years due to the higher rates of trimethoprim non-susceptibility in this age group. These targets will be reviewed in 2018-19 to ensure that they reflect the latest activity and to maximise appropriate reduction gains.

Another indicator is the sustained reduction of inappropriate prescribing in ambulatory care. For this indicator, the target to be achieved is that the number of prescribed items per Specific Therapeutic group AgeSex Related Prescribing Unit (STAR-PU) [26] must be equal to or below the 2013-14 baseline mean performance value for England of 1.161 items per STAR-PU. This threshold will remain for the period 2018-19.

For hospital care, the main indicator is the reduction in antibiotic consumption per 1,000 admissions (both for inpatients and outpatients) measured as DDD per 1,000 admissions against the $2013-14$ baseline. This main indicator has three parts: total antibiotic consumption, carbapenem consumption and piperacillintazobactam consumption. The target to be achieved in $2017-18$ is a $1 \%$ reduction for those hospital trusts with 2016 consumption indicators below the 2013-14 median value or a $2 \%$ reduction for those hospital trusts with 2016 consumption indicators above the 2013-14 median value.

The data collected are publically available in the Fingertips website and show a $4.3 \%$ reduction in antibiotic consumption between 2014-15, from 22.9 to 21.8 DDD per 1,000 inhabitants per day. Furthermore, between 2014-15 and 2015-16 the median proportion 
of antibiotics prescribed in the community that were broad-spectrum reduced from $10.8 \%$ to $9.6 \%[27,28]$.

Scotland has developed a 5-year (2016-21) Scottish Antimicrobial Resistance and Healthcare Associated Infection (SARHAI) Strategy [29] and a 2014-18 action plan for the management of antimicrobial resistance (ScotMARAP 2) [30]. For ambulatory care, the indicator developed by the SARHAI Strategy Group is the reduction of inappropriate antibiotic prescribing. To achieve this goal, practices must either achieve an equivalent or lower prescribing rate to that of the Scottish 25th percentile or achieve an acceptable minimum reduction towards that level. The acceptable minimum level of reduction is defined as a reduction in the number of items per 1,000 patients per day equivalent to one fifth of the national interquartile range.

For hospital care, the Scottish Antimicrobial Prescribing Group (SAPG) has proposed a threefold target (baseline January-December 2015) to reduce antibiotic consumption (measured in DDD per 1,000 admissions): reduction of $1 \%$ or more in total antibiotic consumption against baseline, reduction of $1 \%$ or more in carbapenem consumption against baseline and reduction of $1 \%$ or more in piperacillin-tazobactam consumption against baseline.

At the time of the study, these proposals were under review by the SARHAI policy group in Scotland with a decision expected in early 2018.

Wales and Northern Ireland have also developed strategies to tackle antimicrobial resistance, but no specific targets are currently in place.

\section{United States}

In September 2014, the US published its National Strategy for Combating Antibiotic-Resistant Bacteria [31]. This was followed by a national action plan in 2015 , which provided the steps for implementation of the national strategy [32].

National Strategy Goal 1 is to slow the emergence of resistant bacteria and prevent the spread of resistant infections. It anticipates the following outcomes by 2020: inappropriate inpatient antibiotic use for monitored conditions/agents will be reduced by $20 \%$ from 2014 levels and inappropriate outpatient antibiotic use for monitored conditions/agents will be reduced by $50 \%$ from 2010 levels.

In 2016, the CDC characterised antibiotic use, both in children and in adults, in ambulatory care based on the 2010-11 National Ambulatory Medical Care Survey and National Hospital Ambulatory Medical Care Survey. Annual numbers and population-adjusted rates of ambulatory visits with oral antibiotic prescriptions by age, region and diagnosis were estimated. This study concluded that in the US, in 2010-11, there was an estimated annual antibiotic prescription rate of 506 per
1,000 inhabitants, but only an estimated 353 of these antibiotic prescriptions were necessary. Therefore, an estimated $30 \%$ of antibiotic courses prescribed in doctor's offices and emergency departments were unnecessary. To reach the goal described in the National Strategy, antibiotic prescribing for ambulatory visits would need to be reduced by $15 \%$ by 2020 .

Another study [33] focused on inappropriate antibiotic selection for otitis media, sinusitis and pharyngitis. These syndromes collectively account for nearly one third of all antibiotics prescribed in US ambulatory settings. Professional guidelines recommend narrowspectrum antibiotics as first-line therapy for these conditions, except in patients with penicillin allergy (ca $10 \%$ of the US population reports a penicillin allergy) or treatment failures (estimated $10 \%$ ). Therefore, at least $80 \%$ of patient visits for the above conditions should be treated with first-line antibiotics. However, only $52 \%$ of patient visits for these conditions resulted in a prescription of a first-line antibiotic. Therefore, opportunities to improve antibiotic use in ambulatory care to meet 2020 goals involve improving antibiotic selection in addition to reducing unnecessary antibiotic prescribing.

For these nine countries, established targets are described below and the targets are summarised in Table 1.

The remaining 21 countries indicated that they have not established such targets; however, 17 of them indicated that work to establish such targets is underway, often in the context of developing a national action plan against antimicrobial resistance (Table 2).

\section{Discussion and conclusions}

Information on existing targets for the reduction of antibiotic use in humans is limited. Recently, Howard et al. [34] provided a first list of indicators of antibiotic prescriptions when linked to national targets and incentives from members of the European Society of Clinical Microbiology and Infectious Diseases (ESCMID) Study Group for Antimicrobial Stewardship (ESGAP) members. In this TATFAR survey, we collected data from official contacts in EU countries, Norway, Iceland, Canada and the US on such targets-either implemented or under development-with an aim to reduce the use of antibiotics in humans in ambulatory, hospital and long-term care, independently from their link to financial incentives. The additional value of the material presented is modest to what was ascertained by Howard et al [34] providing complementary information on EU countries that are not represented in ESGAP, as well as in the US and Canada. We showed that, as at 2017, only nine countries had implemented targets for the reduction of antibiotic use in humans, while 17 countries had indicated that work is underway to establish such targets. We also collected detailed information on how the targets were defined and measured, showing that the reported targets and corresponding metrics varied 
TABLE 1A

Countries with established objectives and targets for the reduction of antibiotic use in humans, TATFAR survey, 2017 ( $\mathrm{n}=9$ countries)

\begin{tabular}{|c|c|c|c|c|c|c|}
\hline Country & Setting & Objective & Unit of measure & Target & $\begin{array}{l}\text { Year by } \\
\text { which the } \\
\text { target } \\
\text { must be } \\
\text { reached }\end{array}$ & Comments \\
\hline \multirow{3}{*}{ Belgium } & \multirow{3}{*}{$\begin{array}{l}\text { Ambulatory } \\
\text { care }\end{array}$} & $\begin{array}{l}\text { Reduction in total antibiotic } \\
\text { prescription rate }\end{array}$ & $\begin{array}{l}\text { Prescriptions per } 1,000 \\
\text { inhabitants and } \\
\text { per year }\end{array}$ & $\begin{array}{c}\text { From }>800 \\
\text { in } 2014 \text { to } 600 \text { by } 2020 \text { and } \\
400 \text { by } 2025\end{array}$ & $\begin{array}{l}2020 \text { and } \\
2025\end{array}$ & None \\
\hline & & Reduction in quinolone consumption & $\begin{array}{l}\text { Proportion of total antibiotic } \\
\text { consumption }\end{array}$ & From ca $10 \%$ in 2014 to $5 \%$ & 2018 & None \\
\hline & & $\begin{array}{l}\text { Increase in the yearly prescription } \\
\text { ratio for amoxicillin/amoxicillin- } \\
\text { clavulanic acid }\end{array}$ & Not applicable & $\begin{array}{c}\text { From ca } 50 / 50 \text { in } 2014 \text { to } \\
80 / 20\end{array}$ & 2018 & None \\
\hline \multirow{4}{*}{ France } & Alla & $\begin{array}{l}\text { Reduce the total consumption of } \\
\text { antibiotics for systemic use }\end{array}$ & DDD per 1,000 inhabitants per day & $\begin{array}{c}\text { By } 25 \% \\
\text { (cf.d with 2011) }\end{array}$ & 2016 & None \\
\hline & \multirow{3}{*}{$\begin{array}{l}\text { Ambulatory } \\
\text { care }\end{array}$} & $\begin{array}{c}\text { Reduction of antibiotic prescriptions } \\
\text { for patients aged } 16-65 \text { years without } \\
\text { chronic diseases }\end{array}$ & $\begin{array}{l}\text { Number of prescriptions per } 100 \\
\text { patients }\end{array}$ & $\leq 14$ & $\begin{array}{l}\text { December } \\
2017\end{array}$ & $\begin{array}{l}\text { Pay for performance } \\
\text { target for GPs }\end{array}$ \\
\hline & & $\begin{array}{l}\text { Reduce the proportion of patients } \\
\text { treated yearly with 'critical } \\
\text { antibiotics' (amoxicillin-clavulanic } \\
\text { acid, third-and fourth-generation } \\
\text { cephalosporins, fluoroquinolones) }\end{array}$ & $\begin{array}{l}\text { Percentage of all antibiotic } \\
\text { prescriptions }\end{array}$ & $\leq 27 \%$ & $\begin{array}{l}\text { December } \\
2017\end{array}$ & $\begin{array}{l}\text { Pay for performance } \\
\text { target for GPS }\end{array}$ \\
\hline & & $\begin{array}{l}\text { Reduction of the ratio of children } \\
\text { treated with third- or fourth- } \\
\text { generation cephalosporin (as } \\
\text { percentage of children receiving } \\
\text { antibiotics) }\end{array}$ & Not applicable & $\begin{array}{l}<3 \% \text { of children }<4 \text { years old; } \\
<2 \% \text { of children } \geq 4 \text { years old }\end{array}$ & NA & $\begin{array}{l}\text { Pay for performance } \\
\text { target for } \\
\text { paediatricians }\end{array}$ \\
\hline Malta & Hospital care & Reduction of the use of carbapenems & DDD per 1,000 bed-days & $\begin{array}{c}\text { By } 50 \% \\
\text { (cf.d with 2016) } \\
\end{array}$ & 2019 & None \\
\hline Netherlands & All & $\begin{array}{c}\text { Reduction of the proportion of } \\
\text { inappropriately prescribed antibiotics, } \\
\text { across the entire healthcare chain }\end{array}$ & NA & $B y \geq 50 \%$ & 2019 & $\begin{array}{l}\text { Baseline values are } \\
\text { being determined }\end{array}$ \\
\hline \multirow{7}{*}{ Norway } & \multirow{6}{*}{$\begin{array}{l}\text { Ambulatory } \\
\text { care }\end{array}$} & $\begin{array}{l}\text { Reduction of total antibiotic } \\
\text { consumption }\end{array}$ & DDD per 1,000 inhabitants per day & $\begin{array}{c}\text { Bу } 30 \% \\
\text { (cf.d with 2012) }\end{array}$ & 2020 & None \\
\hline & & $\begin{array}{l}\text { Reduction of average total antibiotic } \\
\text { prescription rate }\end{array}$ & $\begin{array}{l}\text { Prescriptions per } 1,000 \\
\text { inhabitants per year }\end{array}$ & 250 & 2020 & None \\
\hline & & $\begin{array}{l}\text { Reduction of antibiotic prescriptions } \\
\text { to treat respiratory infections }\end{array}$ & DDD per 1,000 inhabitants per day & $\begin{array}{c}\text { By } 20 \% \\
\text { (cf.d with 2012) } \\
\end{array}$ & 2020 & None \\
\hline & & $\begin{array}{c}\text { Reduce the proportion of } \\
\text { phenoxymethylpenicillin prescriptions } \\
\text { for respiratory tract infections in } \\
\text { children aged } 0-6 \text { years }\end{array}$ & $\begin{array}{c}\text { Percentage of the total number of } \\
\text { antibiotic prescriptions for this } \\
\text { indication in children aged } 0-6 \\
\text { years }\end{array}$ & $\geq 80 \%$ & NA & $\begin{array}{l}\text { Target from the } \\
\text { national treatment } \\
\text { guidelines }\end{array}$ \\
\hline & & $\begin{array}{l}\text { Reduce the proportion of } \\
\text { fluoroquinolones (and in particular } \\
\text { of ciprofloxacin) prescriptions in } \\
\text { uncomplicated urinary tract infections } \\
\text { in women aged 20-79 years }\end{array}$ & $\begin{array}{c}\text { Percentage of the total number of } \\
\text { antibiotic prescriptions for this } \\
\text { indication in women aged 20-79 } \\
\text { years }\end{array}$ & $\leq 8 \%$ & NA & $\begin{array}{l}\text { Target agreed } \\
\text { by the National } \\
\text { Antibiotics } \\
\text { Committee }\end{array}$ \\
\hline & & $\begin{array}{c}\text { Reduction of prescription rate of } \\
\text { antibiotics for respiratory tract } \\
\text { infections in children aged } 0-6 \text { years }\end{array}$ & DDD per 1,000 inhabitants per day & Bу $30 \%$ & NA & $\begin{array}{l}\text { Target agreed } \\
\text { by the National } \\
\text { Antibiotics } \\
\text { Committee }\end{array}$ \\
\hline & Hospital care & $\begin{array}{l}\text { Reduction of the use of broad- } \\
\text { spectrum antibiotics }\end{array}$ & DDD per 100 beds per day & $\begin{array}{c}\text { By } 30 \% \\
\text { (cf.d with 2012) }\end{array}$ & 2020 & None \\
\hline \multirow{2}{*}{ Slovenia } & $\begin{array}{l}\text { Ambulatory } \\
\text { care }\end{array}$ & $\begin{array}{l}\text { Reduction of total antibiotic } \\
\text { consumption }\end{array}$ & DDD per 1,000 inhabitants per day & $\begin{array}{c}\text { By } 20 \% \\
\text { (cf.d with 2017) }\end{array}$ & 2024 & None \\
\hline & Hospital care & $\begin{array}{l}\text { Reduction of total antibiotic } \\
\text { consumption }\end{array}$ & DDD per 1,000 inhabitants per day & $\begin{array}{c}\text { By } 10 \% \\
\text { (cf.d with 2017) }\end{array}$ & 2024 & None \\
\hline
\end{tabular}

cf.d.: compared; DDD: defined daily dose; GPs: general practitioners; IQR: interquartile range; NA: not available; STAR-PU: Specific therapeutic group age-sex related prescribing unit; TATFAR: Transatlantic Taskforce on Antimicrobial Resistance; UK: United Kingdom; US: United States.

a In all instances herein, 'All' refers to ambulatory and hospital care. 
TABLE 1B

Countries with established objectives and targets for the reduction of antibiotic use in humans, TATFAR survey, 2017 ( $\mathrm{n}=9$ countries)

\begin{tabular}{|c|c|c|c|c|c|c|}
\hline Country & Setting & Objective & Unit of measure & Target & $\begin{array}{l}\text { Year by } \\
\text { which the } \\
\text { target } \\
\text { must be } \\
\text { reached }\end{array}$ & Comments \\
\hline \multirow{9}{*}{ Sweden } & \multirow{7}{*}{$\begin{array}{l}\text { Ambulatory } \\
\text { care }\end{array}$} & $\begin{array}{l}\text { Reduce total antibiotic prescription } \\
\text { rate }\end{array}$ & $\begin{array}{l}\text { Prescriptions per } 1,000 \\
\text { inhabitants per year }\end{array}$ & $\leq 250$ & NA & None \\
\hline & & $\begin{array}{c}\text { Increase proportion of } \\
\text { phenoxymethylpenicillin commonly } \\
\text { used to treat respiratory tract } \\
\text { infections in children aged } 0-6 \text { years }\end{array}$ & $\begin{array}{c}\text { Percentage of the total number of } \\
\text { antibiotic prescriptions for this } \\
\text { indication in children aged } 0-6 \\
\text { years }\end{array}$ & $\geq 80 \%$ & NA & None \\
\hline & & $\begin{array}{c}\text { Decrease proportion of } \\
\text { fluoroquinolones vs all antibiotics } \\
\text { commonly used to treat urinary tract } \\
\text { infections in women aged } 18-79 \text { years }\end{array}$ & $\begin{array}{c}\text { Percentage of the total number of } \\
\text { antibiotic prescriptions for this } \\
\text { indication in women aged } 18-79 \\
\text { years }\end{array}$ & $\leq 10 \%$ & NA & None \\
\hline & & $\begin{array}{c}\text { Increase of the proportion of first } \\
\text { line treatment to treat urinary tract } \\
\text { infections in women with afebrile } \\
\text { urinary tract infection }\end{array}$ & $\begin{array}{l}\text { Percentage of the total number of } \\
\text { antibiotic prescriptions for this } \\
\text { indication in women }\end{array}$ & $>80 \%$ & NA & $\begin{array}{l}\text { Target suggested } \\
\text { by the Strama } \\
\text { Programme Council } \\
\text { operational plan }\end{array}$ \\
\hline & & $\begin{array}{c}\text { Increase of the proportion of first } \\
\text { line treatment to treat urinary tract } \\
\text { infections in men with afebrile urinary } \\
\text { tract infection }\end{array}$ & $\begin{array}{l}\text { Percentage of the total number of } \\
\text { antibiotic prescriptions for this } \\
\text { indication in men }\end{array}$ & $>50 \%$ & NA & $\begin{array}{l}\text { Target suggested } \\
\text { by the Strama } \\
\text { Programme Council } \\
\text { operational plan }\end{array}$ \\
\hline & & $\begin{array}{l}\text { Increase of the proportion of patients } \\
\text { treated against pharyngotonsilitis } \\
\text { who receive penicillin } V\end{array}$ & $\begin{array}{c}\text { Percentage of the total number } \\
\text { of antibiotic prescriptions for } \\
\text { pharyngotonsilitis }\end{array}$ & $>90 \%$ & NA & $\begin{array}{l}\text { Target suggested } \\
\text { by the Strama } \\
\text { Programme Council } \\
\text { operational plan }\end{array}$ \\
\hline & & $\begin{array}{c}\text { Decrease of the proportion of patients } \\
\text { with acute bronchitis who receive } \\
\text { antibiotic treatment }\end{array}$ & $\begin{array}{l}\text { Percentage of the total number of } \\
\text { patients with acute bronchitis }\end{array}$ & $<10 \%$ & NA & $\begin{array}{l}\text { Target suggested } \\
\text { by the Strama } \\
\text { Programme Council } \\
\text { operational plan }\end{array}$ \\
\hline & \multirow{2}{*}{ Hospital care } & $\begin{array}{l}\text { Increase proportion of patients with } \\
\text { community-acquired pneumonia not } \\
\text { requiring intensive care, initially } \\
\text { treated with penicillin }\end{array}$ & $\begin{array}{c}\text { Percentage of the total number of } \\
\text { patients with community-acquired } \\
\text { pneumonia not requiring intensive } \\
\text { care }\end{array}$ & $>60 \%$ & NA & $\begin{array}{l}\text { Target suggested } \\
\text { by the Strama } \\
\text { Programme Council } \\
\text { operational plan }\end{array}$ \\
\hline & & $\begin{array}{l}\text { Increase proportion of patients } \\
\text { with afebrile urinary tract infection } \\
\text { receiving first line treatment }\end{array}$ & $\begin{array}{c}\text { Proportion of the total number of } \\
\text { patients with afebrile urinary tract } \\
\text { infection }\end{array}$ & $>90 \%$ & NA & $\begin{array}{l}\text { Target suggested } \\
\text { by the Strama } \\
\text { Programme Council } \\
\text { operational plan }\end{array}$ \\
\hline \multirow{5}{*}{ UK } & \multirow{2}{*}{$\begin{array}{l}\text { Ambulatory } \\
\text { care } \\
\text { (England) }\end{array}$} & $\begin{array}{l}\text { Reduction of inappropriate antibiotic } \\
\text { prescribing for urinary tract infections }\end{array}$ & $\begin{array}{c}\text { Trimethoprim/nitrofurantoin } \\
\text { prescribing ratio and number of } \\
\text { trimethoprim items prescribed to } \\
\text { patients aged } \geq 70 \text { years }\end{array}$ & $\begin{array}{c}\text { At least a } 10 \% \text { reduction in } \\
\text { both (cf.d with June 2015-May } \\
\text { 2016) }\end{array}$ & NA & $\begin{array}{l}\text { Pay for performance } \\
\text { target (valid until } \\
\text { 2018) }\end{array}$ \\
\hline & & $\begin{array}{l}\text { Reduce inappropriate prescribing in } \\
\text { ambulatory care }\end{array}$ & $\begin{array}{c}\text { Number of prescribed items per } \\
\text { STAR-PU }\end{array}$ & $\begin{array}{c}\text { Equal to or below the } 2013-14 \\
\text { baseline mean performance } \\
\text { value for England of } 1.161 \\
\text { items per STAR-PU }\end{array}$ & NA & $\begin{array}{l}\text { Pay for performance } \\
\text { target (valid until } \\
\text { 2019) }\end{array}$ \\
\hline & $\begin{array}{l}\text { Ambulatory } \\
\text { care } \\
\text { (Scotland) }\end{array}$ & $\begin{array}{c}\text { Reduction of inappropriate antibiotic } \\
\text { prescribing }\end{array}$ & $\begin{array}{l}\text { Number of items per } 1,000 \\
\text { patients per day }\end{array}$ & $\begin{array}{l}\text { Prescribing rate } \leq \text { that of } \\
\text { the Scottish } 25 \text { th percentile } \\
\text { or achieve an acceptable } \\
\text { minimum reduction towards } \\
\text { that level; the acceptable } \\
\text { minimum level of reduction is } \\
\text { defined as a reduction in the } \\
\text { number of items per } 1,000 \\
\text { patients per day equivalent to } \\
\text { one fifth of the national IQR }\end{array}$ & NA & None \\
\hline & $\begin{array}{l}\text { Hospital care } \\
\text { (England) }\end{array}$ & $\begin{array}{l}\text { Reduction in consumption of all } \\
\text { antibiotics (total), carbapenems } \\
\text { piperacillin-tazobactam }\end{array}$ & DDD per 1,000 admissions & $\begin{array}{l}\text { By } 1 \% \text { (cf.d with } 2013-14 \text { ) } \\
\text { for those trusts with } 2016 \\
\text { consumption indicators below } \\
\text { the } 2013-14 \text { median value } \\
\text { or by } 2 \% \text { (cf.d with } 2013-14 \text { ) } \\
\text { for those trusts with } 2016 \\
\text { consumption indicators above } \\
\text { the } 2013-14 \text { median value }\end{array}$ & NA & $\begin{array}{l}\text { Pay for performance } \\
\text { target (valid until } \\
\text { 2018) }\end{array}$ \\
\hline & $\begin{array}{l}\text { Hospital care } \\
\text { (Scotland) }\end{array}$ & $\begin{array}{c}\text { Reduction in consumption of all } \\
\text { antibiotics (total), carbapenems, } \\
\text { piperacillin-tazobactam }\end{array}$ & DDD per 1,000 admissions & $\begin{array}{l}\text { By } 1 \% \text { (cf.d with January- } \\
\text { December 2015). }\end{array}$ & NA & Proposed indicator \\
\hline \multirow{2}{*}{ US } & $\begin{array}{l}\text { Ambulatory } \\
\text { care }\end{array}$ & $\begin{array}{l}\text { Reduction of inappropriate use of } \\
\text { antibiotics for monitored conditions }\end{array}$ & NA & $\begin{array}{c}\text { By } 50 \% \\
\text { (cf.d with 2010) } \\
\end{array}$ & 2020 & None \\
\hline & Hospital care & $\begin{array}{l}\text { Reduction of inappropriate use of } \\
\text { antibiotics for monitored conditions }\end{array}$ & NA & $\begin{array}{l}\text { By } 20 \% \\
\text { (cf.d with 2011) }\end{array}$ & 2020 & None \\
\hline
\end{tabular}


TABLE 2

Countries without established targets for the reduction of antimicrobial use in humans, TATFAR survey, 2017 (n=21)

\begin{tabular}{|c|c|c|}
\hline Country & $\begin{array}{l}\text { Target(s) will be included } \\
\text { in a forthcoming national } \\
\text { action plan }\end{array}$ & Comments \\
\hline Austria & $\mathrm{Y}$ & None \\
\hline Bulgaria & Y & $\begin{array}{l}\text { A preliminary draft of the plan was discussed by experts from the Ministry of Health, } \\
\text { physicians, clinical microbiologists, veterinary and food safety experts and experts from } \\
\text { WHO in September } 2016 \text {. }\end{array}$ \\
\hline Canada & $\mathrm{N}$ & $\begin{array}{l}\text { Canada released Tackling Antimicrobial Resistance and Antimicrobial Use: A Pan-Canadian } \\
\text { Framework for Action in September 2017. This framework is a high-level policy document } \\
\text { that outlines the strategic objectives, outcomes and opportunities to guide collaborative } \\
\text { action on antimicrobial resistance and antimicrobial use. It is grounded in a One Health } \\
\text { approach and was developed in collaboration with federal, provincial and territorial } \\
\text { governments and external stakeholders from academia, non-governmental organisations } \\
\text { and industries representing human health, animal health and agriculture sectors. The } \\
\text { framework is based on four core components: surveillance, infection prevention and } \\
\text { control, stewardship, and research and innovation. An associated action plan will be } \\
\text { finalised in 2019. }\end{array}$ \\
\hline Croatia & $\mathrm{N}$ & $\begin{array}{l}\text { In the ambulatory care sector, there are draft plans to set targets to curb the use of } \\
\text { amoxicillin-clavulanic acid and other combinations of penicillins with beta-lactamase } \\
\text { inhibitors. In the hospital care sector, the first priority will be to enact legislation making } \\
\text { it compulsory to nominate dedicated antibiotic stewardship teams in each hospital; after } \\
\text { this, there are plans to develop targets to reduce the use of specific antibiotics in the } \\
\text { hospital setting. }\end{array}$ \\
\hline Czech Republic & $\mathrm{N}$ & Plans to introduce targets are being developed. \\
\hline Denmark & Y & $\begin{array}{l}\text { A new national action plan with measurable targets for antibiotics for human use is under } \\
\text { finalisation and should be published in } 2017 .\end{array}$ \\
\hline Estonia & $\mathrm{N}$ & $\begin{array}{c}\text { Preliminary discussions to introduce targets have started. It is expected that targets will } \\
\text { be in place after } 2019 .\end{array}$ \\
\hline Finland & Y & $\begin{array}{l}\text { A national action plan is ready, but has not yet been implemented. The main goal will be } \\
\text { the reduction of the use of first-generation cephalosporins. }\end{array}$ \\
\hline Germany & $\mathrm{N}$ & $\begin{array}{l}\text { Work is being done to rationalise the use of antibiotics, in particular broad-spectrum } \\
\text { antibiotics. }\end{array}$ \\
\hline Greece & $\mathrm{Y}$ & None \\
\hline Hungary & $\mathrm{N}$ & None \\
\hline Iceland & $\mathrm{N}$ & None \\
\hline Ireland & $\mathrm{N}$ & None \\
\hline Italy & Y & $\begin{array}{l}\text { At the time of the survey, no national plan against antimicrobial resistance was } \\
\text { available. } .^{a} \text { However, the national plan to fight antimicrobial resistance } 2017-20 \text { was } \\
\text { recently approved and published ( } 2 \text { November } 2017 \text { ), and its main goals and corresponding } \\
\text { quantitative targets focus on reducing the frequency of infections due to antibiotic- } \\
\text { resistant microorganisms and the frequency of healthcare-associated infections, as well } \\
\text { as specific objectives regarding the reduction of antibiotic consumption. }\end{array}$ \\
\hline Latvia & $\mathrm{Y}$ & None \\
\hline Lithuania & Y & $\begin{array}{l}\text { The draft national action plan includes a goal to increase the proportion of narrow- } \\
\text { spectrum penicillins prescribed in ambulatory care by } 5 \% \text { by } 2019 .\end{array}$ \\
\hline Luxembourg & $\mathrm{Y}$ & At the time of the study, Luxembourg had no national antibiotics plan. ${ }^{\mathrm{b}}$ \\
\hline Poland & $\mathrm{N}$ & Preliminary discussions on the introduction of targets have started. \\
\hline Romania & Y & None \\
\hline Slovakia & Y & $\begin{array}{l}\text { In the hospital sector, the main priority will be the reduction of the use of the third- } \\
\text { generation cephalosporins. For the paediatric population, the main goal will be to } \\
\text { prescribe antibiotics based on C-reactive protein test results in } 95 \% \text { of patients. }\end{array}$ \\
\hline Spain & Y & $\begin{array}{l}\text { National targets for ambulatory care and hospital care, as well as specific local targets, } \\
\text { are being considered. Such targets will be developed on the basis of the analysis of } \\
\text { consumption data in ambulatory and hospital care sectors collected from } 2012 \text { until June } \\
2017 \text {, both at the national level and by the Spanish autonomous regions. }\end{array}$ \\
\hline
\end{tabular}

N: no; TATFAR: Transatlantic Taskforce on Antimicrobial Resistance; WHO: World Health Organization; Y: yes.

a In Italy, the national plan to fight antimicrobial resistance 2017-20 was recently approved and published (2 November 2017), its main goals and corresponding quantitative targets focus on reducing the frequency of infections due to antibiotic-resistant microorganisms and the frequency of healthcare-associated infections, as well as specific objectives regarding the reduction of antibiotic consumption.

b Since 2018, the Government of Luxembourg has approved the first national antibiotics plan, which targets a reduction of antibiotic consumption in all healthcare settings. 
greatly between countries. With a few exceptions, it is too early to assess whether the objectives set by these targets have been met.

The selected targets for antimicrobial use were quantitative metrics in the majority of cases and therefore not directly addressing quality. However, it is difficult to assess the appropriateness of individual prescriptions. There is a lack of information linking prescriptions with the diagnostic indication in most countries [34] and even when information from diagnostic coding is available, the quality can be poor [35]. Quantitative metrics that reflect the appropriateness of prescriptions may serve as proxies for quality indicators and for setting targets.

Some countries have applied financial incentives to support the attainment of targets. The feasibility of these incentives depends on regulatory and structural characteristics that are specific for each country and, therefore, these incentives are not directly applicable to other countries. For the same reason, comparison of the efficacy of different objectives is challenging. Despite these limitations, countries that are considering introducing incentives may find the experiences and strategies of other countries useful.

The survey did not address the methodology for selection of specific indicators and targets. Though the rationale was described explicitly for a few countries, it would be useful for other countries to understand the rationale behind more of these selections. However, there is no consensus methodology for setting quantitative targets in healthcare. The baseline situation, feasibility and availability of resources are factors that influence the selection of targets. This topic requires further research.

This review of the existing antibiotic targets in EU Member States, Norway, Iceland, Canada and the US is aimed at providing detailed information to countries willing to engage in the reduction of antibiotic use in humans. Monitoring of countries' progress towards existing targets, possible barriers and facilitators, as well as the assessment of these countries' need to revise their targets, should provide additional key information and may be the objective of a future survey.

European Survey on TATFAR action 1.2 group

Austria - Reinhild Strauß

Belgium- Anne Ingenbleek

Bulgaria- Iva Christova

Croatia - Arjana Tambić Andrašević

Czech Republic - Helena Žemličkova

Denmark - Christina Moloney

Estonia - Pille Märtin

Finland - Jari Jalava
France - Philippe Cavalié

Germany - Tim Eckmanns

Greece - Flora Kontopidou

Hungary- Maria Matuz

Iceland - Thorolfur Gudnason

Ireland - Karen Burns

Italy - Stefania Iannazzo

Latvia - Raina Nikiforova

Lithuania - Rolanda Valintėlienė

Luxembourg - Valérie Guérin

Malta - Michael A. Borg

The Netherlands - Sabine de Greeff

Norway - Martin Steinbakk

Poland - Anna Olczak-Pieńkowska

Romania - Roxana Serban

Slovakia - Eva Schreterova

Slovenia - Milan Čižman

Spain - Antonio López Navas

Sweden - Gunilla Skoog Ståhlgren

United Kingdom - Alan Johnson, Jacqui Reilly

\section{Acknowledgements}

The findings and conclusions in this report are those of the authors and do not necessarily represent the official position of the European Centre for Disease Prevention and Control, the Public Health Agency of Canada, the Norwegian Institute of Public Health or the US Centers for Disease Control and Prevention.

\section{Conflict of interest}

None declared.

Authors' contributions

Fabio D'Atri: developed the questionnaire issued in March 2017 for the purpose of this study, supervised and coordinated the survey process, performed the data analysis and prepared a draft of the manuscript.

Jacqueline Arthur, Hege Salvesen Blix and Lauri A. Hicks: provided input on the preparation of the questionnaire, answered the survey providing country-specific data, reviewed the manuscript.

Diamantis Plachouras: revised and completed the manuscript.

Dominique L. Monnet: reviewed and provided feedback on the questionnaire and reviewed the manuscript.

The European Survey on TATFAR action 1.2 group: answered the survey providing country-specific data, provided feedback and approved the manuscript. 


\section{References}

1. Organisation for Economic Co-operation and Development (OECD). Antimicrobial resistance - policy insights. Paris: OECD; 2016. Available from: http://www.oecd.org/health/healthsystems/AMR-Policy-Insights-November2016.pdf

2. Ministère de la Santé et des Sports [Ministry of Health and Sports]. Public awareness campaigns on the prudent use of antibiotics, European workshop, November 6-7, 2008. Paris: Ministère de la Santé et des Sports; 2009. French. Available from: http://solidarites-sante.gouv.fr/IMG/pdf/Livre_blanc_ Ministere.pdf

3. 2009 EU-U.S. Summit Declaration, 3 November 2009. Available from: https://www.cdc.gov/drugresistance/pdf/nov-3-2009summit-declaration_eno_508.pdf

4. Transatlantic Task Force on Antimicrobial Resistance (TATFAR). Presenting a united front: International taskforce convenes to battle increasing resistance to life-saving drugs. Available from: https://www.cdc.gov/drugresistance/tatfar/news/united front.html

5. Belgian Antibiotic Policy Coordination Commission (BAPCOC). Note de politique pour la législature 2014-2019. [Policy paper for the 2014-2019 term]. Brussels: BAPCOC; 2014. French. Available from: http://organesdeconcertation.sante.belgique. be/sites/default/files/documents/belgische_commissie_voor de coordinatie van het antibioticabeleid-fr/19100224 fr.pdf.

6. Belgian Antibiotic Policy Coordination Commission (BAPCOC). Policy paper for the 2014-2019 term. Brussels: BAPCOC; 2014 Available from: http://consultativebodies.health.belgium. be/sites/default/files/documents/policy paper bapcoc executive_summary_2014-2019_english.pdf

7. Global-PPS Antimicrobial Consumption and resistance. Point prevalence survey. A tool for antibiotic stewardship in hospitals. Presentation by Koen Magerman. Working group Hospital Medicine. 2015. Available from: http:// overlegorganen.gezondheid.belgie.be/sites/default/files/ documents/18nov2015_k.magerman-pps.pdf

8. Ministère du Travail, de l'Emploi et de la Santé [Ministry of Labour, Employment and Health]. Plan national d'alerte sur les antibiotiques 2011-2016. [National alert plan on antibiotics 2011-2016]. Paris: Ministère du Travail, de l’Emploi et de la Santé; 2011. French. Available from: http://solidarites-sante. gouv.fr/IMG/pdf/plan_antibiotiques_2011-2016_DEFINITIF.pdf

9. Ministère des Affaires Sociales et de la Santé. [Ministry of Social Affairs and Health]. Arrêté du 20 octobre 2016 portant approbation de la convention nationale organisant les rapports entre les médecins libéraux et l'assurance maladie signée le 25 août 2016. [Decreee of 20 October 2016 on the approval of the national agreement on the relationship between private physicians and health insurance, signed on 25 August 2016]. Paris: Ministère des Affaires Sociales et de la Santé; 2016. French. Available from: http://convention2016.ameli.fr/wpcontent/uploads/2016/12/Arrete_du_20-10-16__J0_23-10-16_convention_medicale.pdf

10. Ministère des Affaires Sociales et de la Santé [Ministry of Social Affairs and Health]. Avis relatif à l'avenant $n^{\circ} 1$ à la convention nationale organisant les rapports entre les médecins libéraux et l'assurance maladie, signée le 25 août 2016 [Opinion on endorsement No. 1 of the national agreement on the relations between private physicians and health insurance]. Paris: Ministère des Affaires Sociales et de la Santé; 2016. French. Available from: https://www.legifrance. gouv.fr/affichTexte.do?cidTexte=JORFTEXTo00034519792\&cate gorieLien=id

11. Dutch Ministry of Health. Welfare and Sport. Letter to parliament about the approach to antibiotic resistance. The Hague: Dutch Ministry of Health; 2015. Available from: https://www.government.nl/documents/parliamentarydocuments/2015/06/24/letter-to-parliament-about-theapproach-to-antibiotic-resistance

12. Government of the Netherlands. Administrative agreements on antibiotic resistance in healthcare. The Hague: Government of the Netherlands; 2015. Available from: https://www.government.nl/documents/parliamentarydocuments/2015/06/24/administrative-agreements-onantibiotic-resistance-in-healthcare

13. Debets VE, Verheij TJ, van der Velden AWSWAB's Working Group on Surveillance of Antimicrobial Use. Antibiotic prescribing during office hours and out-of-hours: a comparison of quality and quantity in primary care in the Netherlands. $\mathrm{Br}$ J Gen Pract. 2017;67(656):e178-86. https://doi.org/10.3399/ bjgp17X689641 PMID: 28232364

14. Dekker ARJ, Verheij TJM, van der Velden AW. Antibiotic management of children with infectious diseases in Dutch Primary Care. Fam Pract. 2017;34(2):169-74. https://doi. org/10.1093/fampra/cmw125 PMID: 28122841
15. Tyrstrup M, van der Velden A, Engstrom S, Goderis G, Molstad S, Verheij T, et al. Antibiotic prescribing in relation to diagnoses and consultation rates in Belgium, the Netherlands and Sweden: use of European quality indicators. Scand J Prim Health Care. 2017;35(1):10-8. https://doi.org/10.1080/0281343 2.2017.1288680 PMID: 28277045

16. van der Velden AW, Kuyvenhoven MM, Verheij TJ. Improving antibiotic prescribing quality by an intervention embedded in the primary care practice accreditation: the ARTI4 randomized trial. J Antimicrob Chemother. 2016;71(1):257-63. https://doi. org/10.1093/jac/dkv328 PMID: 26490015

17. Norwegian Ministries. National Strategy against Antibiotic Resistance 2015-2020. Oslo: Norwegian Ministry of Health and Care Services; 2015. Available from: https://www.regjeringen. no/contentassets/5eaf66ac392143b3b2054aed9ob85210/ antibiotic-resistance-engelsk-lavopploslig-versjon-fornett-10-09-15.pdf

18. Government Offices of Sweden. Swedish strategy to combat antibiotic resistance 2016. Stockholm: Ministry of Health and Social Affairs; 2016. Available from: http://www.government. se/49bbcf/contentassets/168838e186de455ca7fe868bee9 2d209/swedish-strategy-to-combat-antibiotic-resistance.pdf

19. Strama - samverkan mot antibiotikaresistens [Collaboration against antibiotic resistance]. Stramas mål för antibiotikaanvändning inom öppen vård [The targets of Strama for antibiotic use in ambulatory care]. STRAMA; 2016. Swedish. Available from: http://strama.se/wp-content/ uploads/2016/04/Stramas-mal-for-antibiotikaanvandningenbeskrivning.pdf

20. André M, Vernby A, Odenholt I, Lundborg CS, Axelsson I, Eriksson M, et al. Diagnosis-prescribing surveys in 2000, 2002 and 2005 in Swedish general practice: consultations, diagnosis, diagnostics and treatment choices. Scand J Infect Dis. 2008;40(8):648-54. https://doi. org/10.1080/00365540801932439 PMID: 18979603

21. Skoog G, Struwe J, Cars O, Hanberger H, Odenholt I, Prag $M$, et al. Repeated nationwide point-prevalence surveys of antimicrobial use in Swedish hospitals: data for actions 2003-2010. Euro Surveill. 2016;21(25):1-9. https://doi. org/10.2807/1560-7917.ES.2016.21.25.30264 PMID: 27367646

22. Strama - Samverkan mot antibiotikaresistens [Collaboration against antibiotic resistance]. Verksamhetsplan 2019 för NAG Strama [Action plan 2019 for NAG Strama]. STRAMA; 2019. Swedish. Available from: http://strama.se/wp-content/ uploads/2019/02/Verksamhetsplan-NAG-Strama-2019.pdf

23. UK Department of Health. UK 5 Year Antimicrobial Resistance Strategy 2013 to 2018. London: Department of Health; 2013. Available from: https://www.gov.uk/government/publications/ uk-5-year-antimicrobial-resistance-strategy-2013-to-2018

24. National Health Service England (NHS). Quality Premium guidance 2017-19. London: NHS; 2017. Available from: https://www.england.nhs.uk/resources/resources-for-ccgs/ ccg-out-tool/ccg-ois/qual-prem/

25. National Health Service (NHS) England. 2017-2019 CQUIN Guidance. London: NHS; 2017. Available from: https://www. england.nhs.uk/nhs-standard-contract/cquin/cquin-17-19/

26. The Health and Social Care Information Centre. Prescribing Measures and their application. Health and Social Care Information Centre: Leeds; 2012. Available from: http:// content.digital.nhs.uk/media/10952/Prescribing-Measures/ pdf/CHttpHandler.pdf

27. Johnson AP, Müller-Pebody B, Budd E, Ashiru-Oredope $D$, Ladenheim D, Hain D, et al. Improving feedback of surveillance data on antimicrobial consumption, resistance and stewardship in England: putting the data at your Fingertips. Antimicrob Chemother. 2017;72(4):953-6. PMID: 27999049

28. Public Health England (PHE). English surveillance programme for antimicrobial utilisation and resistance. London: PHE; 2016. Available from: https://www.gov.uk/government/uploads/ system/uploads/attachment_data/file/570276/ESPAUR_ executive_summary_and_recommendations.pdf

29. Scottish Government. Scottish Antimicrobial Resistance (AMR) and Healthcare Associated Infections (HAI) 5 year Strategic Framework. Edinburgh: The Scottish Government; 2016. Available from: http://www.gov.scot/ Topics/Health/Services/Preventing-Healthcare-Infections/ SARHAI5YrStrategicFramework

30. National Health Service (NHS) Scotland. Scottish Management of Antimicrobial resistance Action Plan 2014 - 18 (ScotMARAP 2). Edinburgh: NHS Scotland; 2014. Available from: http:// www.scottishmedicines.org.uk/files/sapg/ScotMARAP2_final. pdf

31. The White House. National strategy for combating antibiotic resistant bacteria. Washington D.C.: the White House; 2014 Available from: https://www.cdc.gov/drugresistance/pdf/ carb national strategy.pdf 
32. The White House. National action plan for combating antibioticresistant bacteria. Washington D.C.: The White House; 2015.

Available from: https://www.cdc.gov/drugresistance/pdf/ national_action_plan_for_combating_antibotic-resistant bacteria.pdf

33. Hersh AL, Fleming-Dutra KE, Shapiro DJ, Hyun DY, Hicks LAOutpatient Antibiotic Use Target-Setting Workgroup. Outpatient Antibiotic Use Target-Setting Workgroup.

Outpatient Antibiotic Use Target-Setting Workgroup. Frequency of first-line antibiotic selection among US ambulatory care visits for otitis media, sinusitis, and pharyngitis. JAMA Intern Med. 2016;176(12):1870-2. https://doi.org/10.1001/ jamainternmed.2016.6625 PMID: 27775770

34. Howard P, Huttner B, Beović B, Béraud G, Kofteridis DP, Paño Pardo J, et al. ESGAP Indicators Working Group. ESGAP inventory of target indicators assessing antibiotic prescriptions: a cross-sectional survey. J Antimicrob Chemother. 2017;72(10):2910-4. https://doi.org/10.1093/jac/ dkx243 PMID: 29091207

35. Smieszek T, Pouwels KB, Dolk FCK, Smith DRM, Hopkins $S$, Sharland $M$, et al. Potential for reducing inappropriate antibiotic prescribing in English primary care. J Antimicrob Chemother. 2018;73(suppl_2):ii36-43. PMID: 29490058

\section{License, supplementary material and copyright}

This is an open-access article distributed under the terms of the Creative Commons Attribution (CC BY 4.0) Licence. You may share and adapt the material, but must give appropriate credit to the source, provide a link to the licence and indicate if changes were made.

Any supplementary material referenced in the article can be found in the online version.

This article is copyright of the authors or their affiliated institutions, 2019. 